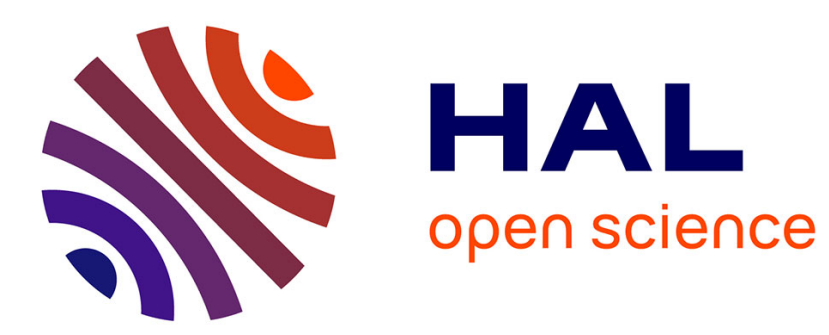

\title{
The cash is in the medium, not in the machine: Toward the golden moments of $3 \mathrm{D}$ printing
}

Steffen Roth

\section{To cite this version:}

Steffen Roth. The cash is in the medium, not in the machine: Toward the golden moments of 3D printing. 2015. hal-01206562

HAL Id: hal-01206562

https://hal-rennes-sb.archives-ouvertes.fr/hal-01206562

Preprint submitted on 29 Sep 2015

HAL is a multi-disciplinary open access archive for the deposit and dissemination of scientific research documents, whether they are published or not. The documents may come from teaching and research institutions in France or abroad, or from public or private research centers.
L'archive ouverte pluridisciplinaire HAL, est destinée au dépôt et à la diffusion de documents scientifiques de niveau recherche, publiés ou non, émanant des établissements d'enseignement et de recherche français ou étrangers, des laboratoires publics ou privés. 


\title{
The cash is in the medium, not in the machine: Toward the golden moments of 3D printing
}

\author{
Steffen Roth* \\ ESC Rennes School of Business \\ 2 Rue Robert d'Abrissel, 35000 Rennes, France \\ E-mail: steffen.roth@esc-rennes.fr \\ *Corresponding author
}

\begin{abstract}
Since 3D printing technology has been available as early as in the early $19^{\text {th }}$ century, the present article start from the question why this radical and probably disruptive technology has been observed as only incremental innovation for so long time. In answering this question, we assume that this incrementalization of the supposed key to the next industrial revolution occurred due to circumstances that complicated and complexed the observation, with the most important of which being that 3D printers do not print on the medium, but rather print the medium, which emerges as form. In this article, this paradox is unfolded in the form of a form-theoretical theory statement on the inherently paradox nature of observation, subsequent to which 3D printing can be observed as both form and medium. In exploring this paradox, we will show that suppliers of 3D printing solutions currently try to sell 3D printing as form, whereas demanders observe 3D printing as medium. In focussing the latter side of the distinction, we finally suggest that the key to successful 3D printing business models will be in solutions that relate observations of the technological multifunctionality of $3 \mathrm{D}$ printing to a social multifunctionality lens.
\end{abstract}

Keywords: 3D printing; form theory; golden moment; technology marketing.

Reference to this paper should be made as follows: Roth, S. (201X) 'The cash is in the medium, not in the machine: Toward the golden moments of $3 \mathrm{D}$ printing', Int. $J$. Manufacturing Technology and Management, Vol. XX, No. X, pp.XXX-XXX.

Biographical notes: Dr. Steffen Roth is tenured Assistant Professor of Management and Organization at ESC Rennes School of Business, Affiliate Professor at the Yerevan State University Department of Sociology, and Visiting Professor at the International University of Rabat School of Business. He was awarded a PhD in management from Chemnitz University 
of Technology, and holds a $\mathrm{PhD}$ in sociology from the University of Geneva. He was visiting professor at the University of Cagliari, the Copenhagen Business School, and the Yerevan State University. His research fields include organization theory, functional differentiation, total markets, next societies, ideation and crowdsourcing, and culturomics.

\section{3D printing in 1801: Introduction to a paradox machine}

The first digital 3D printer in history was demonstrated as early as 1801 . Once programmed, "layer by layer" (Koc and Gurusamy, 2008, p. 151), it assembled a particular raw material into a 3-dimensional object, which appears 2-dimensional only if we observe it from the wrong angle. Aside from such 1-dimensional views of cloth, in general, and double cloth, in particular, the fruits of the Jacquard loom add the necessary depth to a fructuous discussion on 3D printing. In looking at more contemporary definitions of 3D printing (Birtchnell and Urry, 2013; Lipson and Kurman, 2013; Rayna and Striukova, 2014b; Taufik and Jain, 2013), Jacquard weaving effectively represents an early application of the technology: The process is additive, the output is 3-dimensional, and the corresponding machine is automatically controlled by the Jacquard head, which is likely the first binary information processor (Marculescu et al., 2003; Park and Jayaraman, 2001) in history. Jacquard looms are still used for 3D printing today (Mouritz et al., 1999), while the Jacquard head and the punch cards containing the weaving patterns are rightly considered early forms of computation hardware and software (Essinger, 2004; Fernaeus et al., 2012; Goldstine, 1972; Goldstine, 1977; Manovich, 2001).

Computer-controlled 3D printing can hence be traced back to the early days of the industrial revolution, the dawn of another phase of which the technology is observed to herald these days (Berman, 2012; Anderson, 2012; Rifkin, 2011). Nothing more natural to sociology than reloading the social question now, and political or political economic sociology may indeed find good reasons to engage in anticipations of digital Weaver's Revolts. To economic sociology, however, the already quite long history of $3 \mathrm{D}$ printing rather gives reason to 
wonder why a technology, which had proofed feasible and viable as early as in the $19^{\text {th }}$ century, has (only) recently been rediscovered as key to yet another industrial revolution. The initial question that motivated the present article is hence why the widespread, radical, and probably disruptive technological innovation of $3 \mathrm{D}$ printing has been observed as only incremental innovation for so long time. In answering this question, we start from the assumption that this incrementalized observation of the possible key technology of the next industrial revolution occurred due to circumstances that complicated and complexed the observation. 3D printing is indeed particularly hard to observe, first because it represents a technology bundle rather than a distinct technology. Second, this bundle involves computers, the observation of which was hardly possible two hundred years ago and still is challenging these days. Third, the apparently manifest novelty in $3 \mathrm{D}$ printing is in the fact that the peripheral does not print on the medium, but rather prints the medium, which emerges as form.

By the observation of the latter paradox at the latest, we realize that the observation of $3 \mathrm{D}$ printing is very much about the observation of paradoxes, which is something most people are neither enthusiastic about nor trained in. Then linchpin to the diffusion of the technology (Rogers, 2003) as well as the corresponding competitive advantages (Gerhard et al., 2012) and business models (Rayna and Striukova, 2014b) is hence the strategic deparadoxification of 3D printing. The present article pursues this mission by making things worse at first: In fact, our theory statement starts from the idea that the only form in which a paradox can be solved in is a bigger paradox. This paradox is then unfolded in the form of a form-theoretical theory statement on the inherently paradox nature of observation, subsequent to which we will find it intriguing to observe 3D printing as both form and medium. In doing so, we will show that suppliers of 3D printing solutions currently try to sell $3 \mathrm{D}$ printing as form, whereas demanders observe 3D printing as medium. In focussing the latter side of the distinction, we finally suggest that the key to successful business models will be in solutions that relate observations of the technological multifunctionality of $3 \mathrm{D}$ printing to a social multifunctionality lens (Roth, 2014c; Roth, 2015a). 


\section{Forms and media: A recoding of the observation paradox}

The following theory statement is also a methodology statement insofar as we reject the categorical separation of theory and method. True to Norbert Elias (1978), theories also act as methodologies whenever they apply their own distinctions to themselves, thus indicating how their observations appear and can be made to reappear. The quality of such theory-methods is therefore not measured against the number of problems they integrate or solve, but rather gauged against the scale and scope of scientific problems they allow to generate (Merton, 1959). As paradoxes are notorious for their problem generating capacity themselves, the systematic observation of paradoxes necessitates a theory-method that is able to generate problems large enough to act as solution in which we can dissolve the paradox. Such a theory-method is present in the form of form theory.

Descriptions of form theory often start from the imagination of an unmarked space (Spencer Brown, 1979; Luhmann, 1993; Luhmann, 1995), in which systems appear as differences that make a difference (Bateson, 1972). Like a blank sheet of paper becomes the present article (and not a love letter) only after the first lines have been drawn, it is the distinctions drawn (Spencer Brown, 1979) that create the world in which they exist. The observation of any form thus implies the emergence of the corresponding medium, the latter of which, however, remains inaccessible to its own observation: "the operation of observing (...) includes the exclusion of the unobservable, including, moreover, the unobservable par excellence, observation itself, the observer-in-operation" (Luhmann, 1995, p. 44). This is true because indication is only possible based on a distinction of distinction and indication (Kauffman, 1987, p. 58). Distinctions are drawn in order to indicate one - and not the other side of the distinction and therefore have to be distinguished from the distinguished. As this paradox applies to all forms of observation, including the observation of mathematical, biological, linguistic or social forms (Spencer Brown, 1979, p. xxix f.), we are left with the paradox observation that observation is an inherently paradox operation: A duality is concurrently unfolded and indicated as a unity. Consequently, we may say that a paradox is 
observed whenever an observation points at the observation itself.

Once we have accepted this surely not too shocking insight, we find that every paradox can be solved by means of a new form of observation, i.e., by moving from one paradox to another. The appeal of a scientific observation of paradoxes is therefore not in their resolution, but rather in finding strategies to "navigate the perceived tension" (Sharma and Good, 2013, p. 97), with the smartest strategy being the observation and resolution of paradoxes by means of other paradoxes.

The best way to encounter paradoxes is hence to engage in the paradox of deparadoxification, three major forms of which have recently been identified (Andersen, 2003): The first form is factual deparadoxification. In observing a form, we both distinguish "this" from "that" and focus on the this-side of the this-and-that. If we are still interested in observing the this-and-that-form as a whole, then our observation will cross from the this-side to the that-side of the form. This crossing, however, calls for time. In involving time, we can solve the factual both-and-problem at the cost of a temporal paradox. We are now finding both that every form of observation is both sides of/and the distinction at the same time and that every form of observation can only be realised in terms of a sequential crossing from one indicated side of the distinction to another. In this second form of observation, observation thus appears as the paradox of the simultaneity of the sequential. At a third level of observation, we finally find that different sequences of observations will result in different information on what is actually present only simultaneously. In other words, we find that different social observers are constituted as different sequences of observational operations and therefore create the world not as a single universe, but rather as a multiverse of observations.

The deparadoxification strategy pursued in the present article combines the first and the second of the above forms of deparadoxification, thus creating the third. The observer designed by this manoeuver is the simple observation program represented in Table 1. 


\begin{tabular}{|l|c|c|c|}
\hline & Form & Code & Medium \\
\hline Form & - & 1 & 1 \\
\hline Code & 1 & - & 0 \\
\hline Medium & 1 & 0 & - \\
\hline
\end{tabular}

Table 1: Formulas of form, code, and medium (own table)

In order to deparadoxify the concepts form, code, and medium, we propose to define:

1) The code as the observation of a form without medium

2) The medium as the observation of a form without code

3) The form as the paradox of the concurrent observation of both code and medium.

If we connive at the fact that code and medium become forms as soon as we indicate them, then our deparadoxification tool will proof helpful as soon as we navigate the paradox technology 3D printing.

\section{Borderline experience: 3D printing as almost tangible co-evolution of form and medium}

As aforementioned, 3D printing in the Jacquard era already followed the same principles as contemporary 3D printing still does today: The original 3D model was recoded as computer program. The information processor unit read the software on the punch cards, which was eventually executed by the loom. The Jacquard loom hence appears as a well-oiled machine as long as we please to observe it as one machine. The point in Jacquard weaving, however, is that the Jacquard head was not an integral part of the so-called Jacquard loom, but rather represented a critical hardware update to certain types of traditional looms, which turned into Jacquard looms once the update was complete. What is more, Jacquard is not reported to have invented any of the technologies involved and may rather take the credit for being the first to incorporate a small series of yet existing technologies into a viable business model (Stonier, 
1992; Koetsier, 2001; Randell, 1994). In focusing the Jacquard head in the middle of the well-selling technology bundle, we find that this piece of early computing hardware is neither a machine nor a medium because it is both a machine and a medium (that acts, e.g., as human-machine interface). If we further recall that all elements of the above technology bundle are or can be computerized these days, then we find that the entire process of Jacquard weaving or $3 \mathrm{D}$ printing, respectively, is neither a compact form nor an elusive medium because it can be observed as both form and medium.

The distinction of form and medium remains nonetheless, or hence, crucial to our understanding of both computers and 3D printing. In fact, computers appear as fundamentally different things depending on whether we observe them as machines (forms) or as media, respectively. If we observe computers as machines, then we are interested in how computers transform inputs into outputs. From this perspective, we find that computers as much as any other machines are useless if they do not perform transformations. If we observe computers as media, however, the opposite is true: Now we expect that the output be as similar to the input as any possible. The ideal medium channels information without any interference, and transformations of the original form appear as deformations now. The computer is thus indeed a proper paradox in terms of an observation that refers back to itself. In the same way, 3D printing can be observed as paradoxical form not only because it is largely computerized these days, but also because it undermines the old-familiar deparadoxification strategies we use in the observation of 2D printing. In looking at letterpress printing, for example, we find it easy to distinguish form from medium as long as we are comfortable with observing how different forms of letters are pressed on a paper medium. ${ }^{1}$ 3D printing, however, breaks with this viewing habit insofar as it recalls the above-mentioned idea that it is the distinctions drawn that make the medium. A 3D printer does clearly not print on but rather prints the medium, thus transforming it into a large variety of desired forms, ${ }^{2}$ while another look at the

\footnotetext{
${ }^{1}$ Yet, even 2D printing can sometimes appear paradoxical if we observe that a traditional letterpress is both a machine (form) that transforms ink and paper to book pages and, in doing so, serves as dissemination medium.

${ }^{2}$ Not to forget that 3D printing normally involves the creation of computer aided designs, i.e., a process in which the computer is not only as a "medium for the production" of truthful master copies of so-called real-life objects, but also for the design of forms that did before not exist outside of the computer context.
} 
output-side allows again for an almost tangible sensation of the co-evolution of form and medium. It is consequently safe to call $3 \mathrm{D}$ printing a paradoxical technology and to assume that corresponding business models are well advised to take into consideration the respective paradoxes. In the subsequent section, we therefore propose to observe forms and functions of 3D printing that emerge if the technology interacts with the above developed deparadoxification tool.

\section{The stage-management of 3D printing: On why suppliers better stop selling the machines}

In developing his answer to the question "Where do markets come from", Harrison White (2000) draws a clear distinction of two sides of production markets: The suppliers on the one side and the buyers on the other, with either side observing the other. However, White champions the idea that this observation is only indirect insofar as the main source of the suppliers' information on the buyers is not the direct observation of these buyers' behavior, but rather the observation of the other suppliers' behaviors; with the same applying vice versa to the buyers.

The idea that suppliers and buyers in production markets benchmark their peer group rather than engaging in speculations on the other group's behaviors is intriguing because it stresses the eigen-logical nature of the two perspectives involved. In combining the observation of distinct market perspectives with the above reflections on form and medium, we find that suppliers and buyer in 3D printing markets have indeed very different views of 3D printing (cf. Figure 1). 


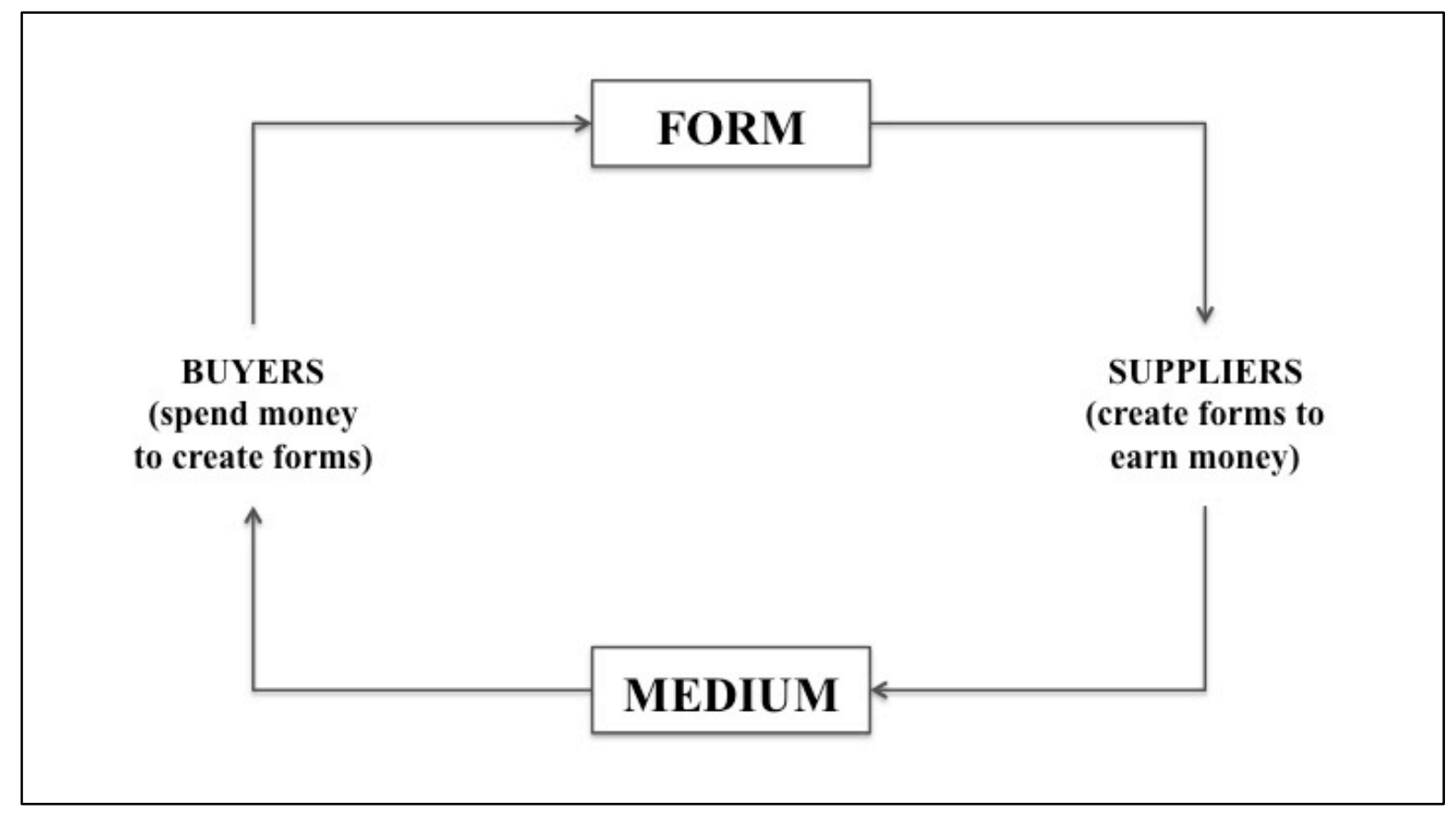

Figure 1: 3D printing as form of making money and medium to create forms

Suppliers conceive of 3D printing as a form of making money. To suppliers, 3D printers are machines that can be sold. Buyers, however, are ultimately not interested in the machine, but rather in a medium they can use to create desired forms. This distinction may appear hairsplitting, which, however, it is not if we think of the difference that this distinction makes in the marketing of the technology.

A natural strategy in the marketing of 3D printing would be to stress the transformative power of the 3D printers. Technology benchmarking would then appear as a proper strategy to divide and rule the market and would allow for the rapid cloning of traditional business models and competitive patterns to the emerging 3D industry. Yet, a focus on the machines' performance effectively absorbs the fascination and creativity of present and future users or customers into rather traditional consumption patterns. Such a technological funneling of expectations actually contradicts all claims for the increasing relevance of customization, user- and customer-integration, or open design as integral components of the technology in general and the industrial revolution it is said to be triggering in particular (Gibson et al., 
2010; Lipson and Kurman, 2013; Raasch et al., 2009; Rayna and Striukova, 2014b; Rayna and Striukova, 2015; Sandanayake and Oduoza, 2006; Vezzetti, 2012). What is more, there is not evidence so far that buyers and users of 3D printing machines and services are actually interested in the aspect of triggering yet another industrial revolution.

If we cross from the supplier to the buyer perspective, however, we find that we can confidently assume that buyers and users are not so much interested in how 3D printing machines work and rather want to know how they can use $3 \mathrm{D}$ printing as a medium in which to realize their needs and desires. The best media, however, are the most unobtrusive, discrete, almost unobservable forms (Heider, 1959; Luhmann, 1995). The tension between technology-focused ballyhooing and a customer needs-focused perspective on $3 \mathrm{D}$ printing is therefore quite fundamental.

If we furthermore agree that the ideal case of $3 \mathrm{D}$ printing is a machine-medium that smoothly turns any material into any form, then the marketing of 3D printing definitely appears as a veritably paradoxical challenge: A machine-focused marketing of 3D printing needs to obtrude the observation of its unobtrusiveness. And a medium-oriented marketing has to find solutions of how to sell highly specific use-cases without corrupting the technology's unique selling proposition, which is in its universality. In this context, particularly explorative approaches to innovation such as experimentation (Petrick and Simpson, 2013), co-creation (Rayna and Striukova, 2010; Rayna and Striukova, 2014b; Rayna and Striukova, 2015; Rayna et al., 2014), freebooting (Bureau, 2014; Chaboud, 2014; Durand and Vergne, 2013; Rayna, 2004; Roth, 2014a; Roth, 2014b), or gamification (Roth et al., 2015; Roth, 2015b) can be considered promising avenues. These perspectives, however, imply a fundamental reorientation in the ways of how we approach business model generation (Gudiksen, 2014; Rayna and Striukova, 2014a), too.

\section{The transparent machine: Toward the golden moments of 3D printing}

Even though it remains likely that suppliers will, for the time being, base their differentiation strategies on a machine-focused benchmarking of 3D printers, the downside of this approach 
is clearly in the circumstance that such a differentiation strategy leads to the disenchantment of the technology. Thus, they risk subverting one of the technology's most valuable selling propositions, which is in the almost magical observation of the fascinatingly paradoxical coevolution of form and medium. We hence suggest to strategically focus rather than problematize or manage out of sight the paradox(es) of 3D printing, with this approach becoming all the more important as we are currently observing the emergence of 4D printing (Ge et al., 2013; Pei, 2014; Tibbits, 2014; Kaivo-Oja et al., 2016) - i.e. the printing of forms that perform intended changes of shape during or soon after their formation - thus adding yet another level in the observation of this particular paradox of observation.

To tap the full - not least economic - potential of 3D printing, suppliers are therefore advised to sell the process of 3D printing rather than the 3D printers. As the golden moment enabled by the technology effectively is in the paradox observation of the co-creation of form and medium, the most important outcome of our form-theoretical observation of 3D printing is clearly that we recommend stage-managing the moment of form-genesis, the observation of which eventually is the unique selling proposition of the technology.

This change of perspective on the 3D printing technology in general and 3D printers in particular certainly implies a narcissistic shock for both the engineers and the businesspeople involved in the design and the commercialization of the product. If the focus is shifted to the moment of form-genesis, then this means that whatever is observed as the machine, i.e., the pride of engineers or product managers, has to be faded into the background of our attention in order to open up the space and occasion for the above golden moments to happen. In concrete terms, this means that the ideal 3D printer is not the kind of black boxes available on the market today, but rather an invisible or at least transparent machine. In the same way, it means that such a discreet, unobtrusive, and inconspicuous machine must not come along with a traditional (price) label anymore, the observation of which would already corrupt the observation of the golden moment.

As the key value proposition of the ideal 3D printer is the real-time satisfaction of the most specific needs, the key challenge of the corresponding business models will be in the 
invention of real-time business models that co-evolve with the process. Due to the high degrees of personal involvement, the golden moments of 3D printing may indeed turn out to be the golden moment of a Pay what you like pricing strategy. A complementary key in the emerging 3D printing industry is therefore in attracting attention to $3 \mathrm{D}$ events that allow for these golden moments to happen, which is in line with the increasing interest in the interface of social media and 3D printing (Hughes, 2012; de Jong and de Bruijn, 2013; Rayna and Striukova, 2015). A promising research direction is therefore not only in a focus on the cultivation of online communities specifically designed by 3D printer suppliers, but also in the exploration of opportunities to link existing or emerging vanity and maker communities, such as etsy.com, dawanda.com, or society6.com with 3D printing hardware. Such links to social media, however, also point at the fact that the businesses of the emerging age of 3D printing industry will need to distinguish themselves by a so-far unknown sensitivity to what is commonly referred to as social factors. A systematic mapping of society in general (Roth, 2014a; Roth, 2015a) and of the non-economic environment of organized economic activities in particular (Roth, 2014c) may therefore help a great deal to create spaces of innovation, in the context of which the economic function is only one among others. Such a new economic modesty is in fact advisable if $3 \mathrm{D}$ printing is expected to act not only as well-audible label for a new type of machines, but also as the necessarily silent background medium of both the next industrial revolution and an equally profound transformation of the contemporary service economy.

\section{References}

1. Andersen, N. Å. (2003) 'The undecidability of decision', Autopoietic organization theory, 235-258.

2. Anderson, C. (2012) Makers: the new industrial revolution, Random House.

3. Bateson, G. (1972) Steps to an ecology of mind: Collected essays in anthropology, psychiatry, evolution, and epistemology, Chicago: University of Chicago Press. 
4. Berman, B. (2012) '3-D printing: The new industrial revolution', Business Horizons, $55(2), 155-162$.

5. Birtchnell, T. and Urry, J. (2013) '3D, SF and the future', Futures, 50, 25-34.

6. Bureau, S. (2014) 'Piracy as an avant-gardist deviance. How do entrepreneurial pirates contribute to the wealth or misery of nations? ', International Journal of Entrepreneurship and Small Business, 22(4), 426-438.

7. Chaboud, M.-C. (2014) 'Pirates never sail alone: Exploring the mechanics of social entrepreneurship involved in software piracy', International Journal of Entrepreneurship and Small Business, 22(4), 519-536.

8. de Jong, J. P. and de Bruijn, E. (2013) 'Innovation lessons from 3-D printing', MIT Sloan Management Review, 54(2), 43-52.

9. Durand, R. and Vergne, J.-P. (2013) The Pirate Organization: Lessons from the Fringes of Capitalism, Harvard Business Press.

10. Elias, N. (1978) What Is Sociology?, London: Hutchinson.

11. Essinger, J. (2004) Jacquard's Web: How a hand-loom led to the birth of the information age, Oxford: Oxford University Press.

12. Fernaeus, Y., Jonsson, M. and Tholander, J. (2012) Revisiting the jacquard loom: threads of history and current patterns in HCI, translated by ACM, 1593-1602.

13. Ge, Q., Qi, H. J. and Dunn, M. L. (2013) 'Active materials by four-dimension printing', Applied Physics Letters, 103(13), 131901. doi:http://dx.doi.org/10.1063/1.4819837.

14. Gerhard, D., Engel, S., Scheiner, C. and Voigt, K.-I. (2012) 'The application of lean principles and its effects in technology development', International Journal of Technology Management, 57(1/2/3), 92-109.

15. Gibson, I., Rosen, D. W. and Stucker, B. (2010) 'Design for additive manufacturing' in Additive Manufacturing Technologies, Springer, 283-316.

16. Goldstine, H. (1972) The Computer from Pascal to Von Neumann, Princeton University Press. 
17. Goldstine, H. (1977) 'A brief history of the computer', Proceedings of the American Philosophical Society, 339-345.

18. Gudiksen, S. (2014) Co-designing business models: Engaging emergence through design games, Aalborg: Aalborg University Press.

19. Heider, F. (1959) 'Thing and Medium', Psychological Issues, 1(3), 1-34.

20. Hughes, I. (2012) 'Virtual worlds, augmented reality, blended reality', Computer Networks, 56(18), 3879-3885. http://dx.doi.org/10.1016/j.comnet.2012.09.016.

21. Kaivo-Oja, J., Ahlqvist, T., Kuusi, O., Linturi, R. and Roth, S. (2016) 'New industrial platforms and radical technology foresight: The case of 3-D printing in Finland and Europe', International Journal of Manufacturing Technology and Management, in this issue.

22. Kauffman, L. H. (1987) 'Self-reference and recursive forms', Journal of Social and Biological Structures, 10(1), 53-72.

23. Koc, B. and Gurusamy, S. P. (2008) 'Geometric algorithms for manufacturing of freeform multi-material objects using reconfigurable tools', International Journal of Manufacturing Technology and Management, 14(1-2), 145-173.

24. Koetsier, T. (2001) 'On the prehistory of programmable machines: musical automata, looms, calculators', Mechanism and Machine Theory, 36(5), 589-603. http://dx.doi.org/10.1016/S0094-114X(01)00005-2.

25. Lipson, H. and Kurman, M. (2013) Fabricated: The new world of $3 D$ printing, Indianapolis: John Wiley \& Sons.

26. Luhmann, N. (1993) 'Deconstruction as Second-Order Observing', New Literary History, 24(4), 763-782.

27. Luhmann, N. (1995) 'The Paradoxy of Observing Systems', Cultural Critique, 31(Fall), 37-55.

28. Manovich, L. (2001) The language of new media, Cambridge, MA: MIT press.

29. Marculescu, D., Marculescu, R., Zamora, N. H., Stanley-Marbell, P., Khosla, P. K., Park, S., Jayaraman, S., Jung, S., Lauterbach, C. and Weber, W. (2003) 'Electronic 
textiles: A platform for pervasive computing', Proceedings of the IEEE, 91(12), 19952018.

30. Merton, R. K. (1959) 'Notes on problem-finding in sociology' in Merton, R. K., Broom, L. and Cottrell Jr, L. S., eds., Sociology Today: Problems and Perspectives, New York: Basic Books, ix-xxxiv.

31. Mouritz, A., Bannister, M., Falzon, P. and Leong, K. (1999) 'Review of applications for advanced three-dimensional fibre textile composites', Composites Part A: applied science and manufacturing, 30(12), 1445-1461.

32. Park, S. and Jayaraman, S. (2001) 'Adaptive and responsive textile structures (ARTS)' in Tao, X., ed. Smart fibres, fabrics and clothing: Fundamentals and applications, Cambridge, UK: Woodhead, 226-245.

33. Pei, E. (2014) '4D printing - revolution or fad?', Assembly Automation, 34(2), 123 127. doi:10.1108/AA-02-2014-014.

34. Petrick, I. J. and Simpson, T. W. (2013) '3D Printing Disrupts Manufacturing: How Economies of One Create New Rules of Competition', Research-Technology Management, 56(6), 12-16.

35. Raasch, C., Herstatt, C. and Balka, K. (2009) 'On the open design of tangible goods', $R \& D$ Management, 39(4), 382-393.

36. Randell, B. (1994) 'The origins of computer programming', IEEE Annals of the History of Computing, 16(4), 6-14.

37. Rayna, T. (2004) 'Piracy and innovation: does piracy restore competition', DRUID Summer Conference.

38. Rayna, T. and Striukova, L. (2010) 'Large-scale open innovation: open source vs. patent pools', International Journal of Technology Management, 52(3/4), 477-496.

39. Rayna, T. and Striukova, L. (2014a) "Few to Many': Change of Business Model Paradigm in the Video Game Industry', Communications \& Strategies, (94), 61.

40. Rayna, T. and Striukova, L. (2014b) 'The Impact of 3D Printing Technologies on Business Model Innovation' in Benghozi, P. J., Krob, D., Lonjon, A. and Panetto, H., 
eds., Digital Enterprise Design \& Management, Berlin: Springer International Publishing, 119-132.

41. Rayna, T. and Striukova, L. (2015) 'Open Innovation 2.0: Is co-creation the ultimate challenge?', International Journal of Technology Management, 69(1), 38-53. 10.1504/IJTM.2015.071030.

42. Rayna, T., Striukova, L. and Darlington, J. (2014) 'Open Innovation, Co-Creation and Mass Customisation: What Role for 3D Printing Platforms?' in Brunoe, T., Nielsen, K., Joergensen, K. and Taps, S., eds., Proceedings of the 7th World Conference on Mass Customization, Personalization, and Co-Creation (MCPC 2014), Aalborg, Denmark, February 4th-7th, 2014, Berlin: Springer, 425-435.

43. Rifkin, J. (2011) The third industrial revolution: how lateral power is transforming energy, the economy, and the world, Macmillan.

44. Rogers, E. (2003) Diffusion of innovations, New York: Free Press.

45. Roth, S. (2014a) 'Booties, Bounties, Business Models. A map to the next red oceans', International Journal of Entrepreneurship and Small Business, 22(4), 439-448.

46. Roth, S. (2014b) 'The eye-patch of the beholder. Introduction to entrepreneurship and piracy', International Journal of Entrepreneurship and Small Business, 22(4), 399407.

47. Roth, S. (2014c) 'The Multifunctional Organization: Two cases for a critical update for research programs in management and organization', Tamara Journal for Critical Organization Inquiry, 12(3), 37-54.

48. Roth, S. (2015a) 'Free economy! On 3628800 alternatives of and to capitalism', Journal of Interdisciplinary Economics, 27(2), 107-128.

49. Roth, S. (2015b) 'Serious Gamification On the Redesign of a Popular Paradox', Games and Culture, online first April 16, 2015. 1555412015581478.

50. Roth, S., Schneckenberg, D. and Tsai, C.-W. (2015) 'The Ludic Drive as Innovation Driver: Introduction to the Gamification of Innovation', Creativity and Innovation Management, 24(2), 300-306. 10.1111/caim.12124. 
51. Sandanayake, Y. and Oduoza, C. (2006) 'Design of a performance measurement system for just-in-time production: a methodological framework', International Journal of Manufacturing Technology and Management, 10(2-3), 276-293.

52. Sharma, G. and Good, D. (2013) 'The Work of Middle Managers Sensemaking and Sensegiving for Creating Positive Social Change', The Journal of Applied Behavioral Science, 49(1), 95-122.

53. Spencer Brown, G. (1979) Laws of form, New York: E. P. Dutton.

54. Stonier, T. (1992) 'The Evolution of Machine Intelligence' in Stornier, T., ed. Beyond Information, Berlin: Springer, 107-133.

55. Taufik, M. and Jain, P. K. (2013) 'Role of build orientation in layered manufacturing: a review', International Journal of Manufacturing Technology and Management, 27(1), 47-73.

56. Tibbits, S. (2014) '4D Printing: Multi-Material Shape Change', Architectural Design, 84(1), 116-121. 10.1002/ad.1710.

57. Vezzetti, E. (2012) 'A knowledge reusing methodology in the product's lifecycle scenario: a semantic approach', International Journal of Manufacturing Technology and Management, 26(1-4), 149-160.

58. White, H. C. (2000) 'Where do markets come from? (Reprinted from American Journal of Sociology, vol 82, pg 517-547, 1981)', Advances in Strategic Management, Vol 17, 2000, 17, 323-350.

Selected publications of Steffen Roth

59. Roth, S. (2014), Fashionable functions. A Google ngram view of trends in functional differentiation (1800-2000), International Journal of Technology and Human Interaction, Vol. 10 No. 2, 34-58.

60. Roth, S. (2014), The things that go without saying. On performative differences between business value communication and communication on business values, International Journal of Business Performance Management, Vol. 15 No. 3, 
175-191.

61. Roth, S. (2014), Coining societies. An inter-functional comparative analysis of the Euro, Innovation: The European Journal of Social Sciences, Vol. 27 No. 4, 99-118.

62. Roth, S. (2013), Common values? Fifty-two cases of value semantics copying on corporate websites, Human Systems Management, Vol. 32 No. 4, pp. 249-265.

63. Roth, S., Kaivo-oja, J. and Hirschmann, T. (2013), Smart regions. Two cases of crowdsourcing for regional development, International Journal of Entrepreneurship and Small Business, Vol. 20 No. 3, pp. 272-285.

64. Roth, S. (2013), Dying is only human. The case death makes for the immortality of the person, Tamara: Journal for Critical Organization Inquiry, Vol. 11 No. 2, pp. 37 41.

65. Roth, S. (2012), Leaving commonplaces on the commonplace. Cornerstones of a polyphonic market theory, Tamara: Journal for Critical Organization Inquiry, Vol. 10 No. 3, pp. 43-52.

66. Roth, S. (2011), Les deux angleterres et le continent. Anglophone sociology as the guardian of Old European semantics, Journal of Sociocybernetics, Vol. 9 No. 1-2, pp. 19-34.

67. Roth, S. (2009), New for whom? Initial images from the social dimension of innovation, International Journal of Innovation and Sustainable Development, Vol. 4 No. 4, pp. 231-252 [VHB].

Edited Volumes and Issues

68. Roth, S. (2014), Entrepreneurship and piracy, Special Issue of the International Journal of Entrepreneurship and Small Business, Vol. 22 No. 4 [FNEGE, CNRS].

69. Roth, S. (2012), The multimedia organization, Special Issue of Tamara: Journal for Critical Organization Inquiry, Vol. 10 No. 3 [ABS].

70. Roth, S., Wetzel, R. and Müller, K. (2011), Non-technological and non-economic 
dimensions of innovation systems, Special Issue of the International Journal of Innovation and Regional Development, Vol. 3, No. 1.

71. Müller, K., Roth, S. and Žák, M. (2010), The social dimension of innovation, Prague, Linde.

72. Roth, S., Scheiber, L. and Wetzel, R. (2010), Organisation multimedial. Zum polyphonen Programm der nächsten Organisation, Heidelberg, Carl Auer.

73. Roth, S. (2009) Non-technological and non-economic innovations: Contributions to a theory of robust innovation, Bern, Peter Lang.

Books

74. Roth, S. (2013) The multimedia organization. Functional differentiations on organizational identity. Geneva, University of Geneva.

75. Roth, S. (2010) Markt ist nicht gleich Wirtschaft. These zur Begründung einer allgemeinen Marktsoziologie. Heidelberg, Carl Auer Verlag.

Book Chapters

76. Roth, S., Mkrtchyan, A. and Vartikyan, A. (2011), Armenia, in Barnett, G. and Golson, J. G. (eds), Encyclopedia of social networks, Thousand Oaks, SAGE Publishing, pp. 56-57.

77. Roth, S. (2010), Zu den Grenzen des Gemeinplatzes vom wirtschaftlichen Markt: Ecksteine einer allgemeinen Marktsoziologie, in Pahl, H. und Meyer, L. (Hrsg), Gesellschaftstheorie der Geldwirtschaft, Marburg, Metropolis.

78. Roth, S. (2009), Introduction. Towards a theory of robust innovation. In Roth, S. (ed.) Non-technological and Non-Economic Innovations: Contributions to a Theory of Robust Innovation, Bern, Peter Lang.

79. Рот, С. (2009), Каковы перспективы краудсорсинга? Транснациональные 
стратегии открытых инноваций для предотвращения “утечки умов” из стран СНГ Перевод с английского, Пипия, Л. К. (сост.), Общественные и гуманитарные науки: тенденции развития и перспективы сотрудничества, М., Ин-т проблем развития науки РАН. 